\title{
TAX WEDGE ON LABOUR AND ITS EFFECT ON EMPLOYMENT GROWTH IN THE EUROPEAN UNION
}

\author{
Primož Dolenc, Suzana Laporšek*
}

\begin{abstract}
:
The paper assesses the characteristics of tax wedge, employment and unemployment rate in the EU and by using linear regression analysis with panel-corrected standard errors on the sample of twenty-seven EU Member States over 1999-2008 period analyzes whether the tax wedge affects the employment growth. The empirical estimates have shown that, with regard to employment and unemployment rate, the EU Member States can be classified into two groups. The first group is characterized with high tax wedge, low employment and high unemployment rate, whereas the second group has the alternative characteristics. The negative tax wedge-employment relation was confirmed in the panel regression analysis, showing that an increase in tax wedge for one percentage point decreases the employment growth in the EU-27 by around 0.04 percentage points, ceteris paribus. The empirical estimates suggest that the EU-27 should continue with the trend of reducing tax wedge, as this would increase employment growth and employment rate and decrease unemployment, especially in Member States with high tax wedge.
\end{abstract}

Keywords: tax wedge, employment growth, economic policy, EU

JEL classification: J30, J38, H24.

\section{Introduction}

The extent to which the tax wedge, a ratio of total labour taxes to total labour costs, affects employment has been the subject of numerous discussions in recent years (OECD, 2008). Namely, by creating a wedge between labour costs to the employer and the corresponding net take-home pay of the employee, taxes on labour in not perfectly flexible labour markets reduce the demand for labour (if demand for labour is not perfectly inelastic) and employment and therefore increase unemployment (Vodopivec, 2005) and intensify exit from the labour force. The existing literature suggests that there is a negative relationship between tax wedge and employment, yet the extent to which an increase in tax wedge results in lower employment appears to be affected by institutional features of the individual labour markets (see for example Alesina and Perotti (1997), Elmeskov et al. (1998), Nickell and Layard (1999), Daveri and Tabellini (2000), Nickell (2003), Belot and van Ours (2004), Bassanini and Duval (2006), Góra et al. (2006)).

In recent years most of the OECD countries and the EU Member States started to reduce the tax wedge on labour in order to alleviate the unemployment problems,

* UP Faculty of Management Koper, Cankarjeva 5, SI-6104 Koper (primoz.dolenc@fm-kp.si, suzana. laporsek@fm-kp.si) 
stimulate job creation and improve general economic framework (OECD, 2006; European Commission, 2005). In OECD countries the tax wedge decreased on average by 0.9 percentage points over 2000-2008 period, by which the decrease was higher amongst the EU OECD countries. On the other hand, in the EU-27 the tax wedge decreased by 2.4 percentage points over the same period (European Commission, 2009a). On overall, the tax wedge and unemployment rate are still significantly higher in most of the EU Member States compared to non-EU OECD countries, also as a result of labour market protection mechanisms in some of the European countries (see OECD, 2006, 2008, 2009a).

The objective of this paper is to assess characteristics of tax wedge on labour, employment and unemployment rate in the EU Member States, differences in tax wedge between NMS-12 and EU-15 and reasons for them and finally, to analyze the impact of tax wedge on employment growth in the EU.

In order to explain the characteristics of tax wedge, employment and unemployment rate in the EU, we apply simple descriptive statistics. To identify groups of EU countries that are similar to each other with regard to employment and unemployment rate we use hierarchical cluster analysis (Ward's method). Further, we use cross plots and linear regression with panel-corrected standard errors on the sample of twenty-seven EU Member States over the years 1999-2008 to investigate the impact of tax wedge on employment growth in the EU. Research based on the latest data (for the period from 1999 to 2008) and trends on tax wedge, employment and unemployment rate in the EU-27 and an analysis of differences between high and low tax wedge countries, in our opinion, present an important value-added compared to previous cross-country studies on the sample of European countries (for example Góra et al., 2006; Võrk et al., 2006; Behar, 2009).

The rest of the paper is structured in the following way. Section 2 gives a brief overview of previous empirical studies on the impact of tax wedge on employment, followed by the presentation of data and methodology in Section 3. Section 4 in detail discusses characteristics of tax wedge, employment and unemployment rate in the EU Member States. Section 5 uses panel data regression analysis to study the relationship between tax wedge and employment growth in the EU. Section 6 concludes and gives relevant policy recommendations.

\section{Previous Empirical Studies on the Tax Wedge}

In a classical framework of labour demand and labour supply, the increase of tax wedge can be presented by a downward shift in the labour demand curve. The more elastic is the labour supply curve (and/or demand curve), the higher is the negative effect of tax wedge on employment (see World Bank, 2005). The latter has been the subject of numerous theoretical and empirical studies, which tried to explain diverse microeconomic and macroeconomic factors influencing the tax wedge-employment relationship.

On a macro-level, there are quite a few macroeconomic empirical studies on tax wedge-employment relationship. They are mostly based on different panel datasets of countries and on econometric models with employment measure as dependent variable, various measures of tax burden on labour as explanatory variables and set 
of control variables (such as GDP, inflation rate, standard market labour institutions, etc.). Despite differences in the structure of the econometric models, the majority of studies shows a negative relationship between tax wedge and employment. The brief structure and results of these studies are summarized in de Haan et al. (2003), Nickell (2003) and OECD (2006).

Nickell and Layard (1999) showed by the panel analysis on 20 OECD countries between 1983-1994 that a decrease in average tax wedge (that includes payroll, income and consumption taxes) for 5 percentage points would reduce the unemployment rate by 13 per cent. Moreover, Nickell (2003) reported that a 10 percentage point rise in the tax wedge reduces labour input of the working age population by somewhere between 1 and 3 per cent. By comparing the big three countries of continental Europe (France, Germany and Italy) with the United States, Nickell (2003) showed that the difference in the tax wedge (around 16 percentage points) explains around one quarter of the overall difference in the employment rate. The remained difference could be explained by substantial differences in the social security system and in other labour market institutions.

Alesina and Perotti (1997) on the sample of 14 OECD countries empirically confirmed the theoretical model which showed that an increase in redistribution financed by an increase in labour taxes leads to an increase in the unit labour cost and therefore induces a loss of competitiveness. In turn, the loss of competitiveness causes a reduction in the demand for exports and a fall in employment in all sectors of the domestic economy.

Daveri and Tabellini (2000) showed that the negative effect of labour taxation on employment and growth is a European phenomenon (correlation is strong and evident in highly unionized countries of continental Europe and much less so in OECD countries with competitive labour markets and in the Scandinavian countries with highly centralized trade unions). Their empirical research on the sample of 14 OECD industrial countries during the period 1965-1991 has pointed that the rise of almost 10 percentage points in the rate of effective labour taxes can account for a 4 percentage points increase in European unemployment. Moreover, the rise of labour taxes is also associated with a reduction of the EU growth rate of about 0.4 percentage points a year and about one third of the observed reduction in growth between 1965-75 and 1976-91.

Bassanini and Duval (2006) as well investigated the influence of labour taxation and possible interactions between taxation and other policies on employment and unemployment on the sample of 21 OECD countries during 1983 and 2003. The study found that in the "average" OECD country, high and long-lasting unemployment benefits and high tax wedge increase aggregate unemployment and lower employment prospects. By contrast, highly centralized and/or coordinated wage bargaining systems are estimated to reduce unemployment. Empirical results have shown that a 10 percentage points reduction of the tax wedge in an average OECD country would reduce equilibrium unemployment by 2.8 percentage points and increase the employment rate by a larger 3.7 percentage points (due to the positive impact on participation).

Similar results were obtained in the studies based on the samples of EU Member States. For example, Góra et al. (2006) showed a negative effect of tax wedge on employment growth in eight NMS and provided evidence that tax wedge more strongly 
affects employment rates among low-skilled workers, but high-skilled are rather immune from this effect. Võrk et al. (2006) showed the negative impact of tax wedge on labour force participation and employment rate in NMS-8. The detrimental effect of high tax wedges and/or inappropriate benefits systems on the generation of desirable labour market outcomes on the sample of 10 Central and Eastern EU Member States (CEE-10) was also shown in the study of Behar (2009).

Although most of the studies confirm the negative effect of tax wedge on employment, the exact magnitude of this relationship depends mainly on institutional features of the individual labour markets (Góra et al., 2006):

- regulations concerning minimum wages and unemployment benefits (see for example Koskela (2001), Kugler and Kugler (2003), Nickell (2003), OECD (2003, 2004, 2007), Ederveen and Thissen (2004), Vodopivec et al. (2005), Vodopivec (2006), Alphametrics (2009), Behar (2009));

- tax incidence share between employer and employee (see for example Gruber (1997), Goerke (1999), Koskela (2001), Nickell (2003));

- skill level of the labour force (see for example OECD (2003, 2004), European Commission (2005), Góra et al. (2006));

- real wage rigidity and prevailing structure of wage bargaining (see also for example Muysken et al. (1999), García and Sala (2006)) and

- other market policies and institutions (see for example Flaig and Rottmann (2007), Koskela and Schöb (2007), European Commission (2009a)).

\section{Data and Methodology}

The methodological scope of this paper is threefold. Firstly, we examine the size of the tax wedge, employment rate and unemployment rate in the EU Member States in 2008 by using simple descriptive statistics.

Because of heterogeneity in the analyzed data, we further apply hierarchical cluster analysis (based on Ward's method) to identify whether there are more homogenous groups of countries and analyze characteristics of obtained homogenous groups.

Finally, to analyze whether variation in tax wedge can explain variation in employment and unemployment rates in the EU, we apply two-variable cross-country scatter diagrams and macro-level panel regression analysis on the sample of twentyseven EU Member States between 1999 and 2008. The following regression model (1) has been estimated:

$$
E G_{i, t}=\alpha+\beta \cdot T W_{i, t}+\Pi \cdot \text { macroenocomic control matrix }_{i, t}+e_{i, t}
$$

where $E G$ - employment growth, $T W$ - tax wedge, macroeconomic control variables, $e$ - error, $i, t$ - country and time.

The regression analysis was assessed by the linear regression with panel-corrected standard errors method, in order to control for contemporaneously correlated and panel heteroskedastic errors (see Beck and Katz, 1995). 
The decision to use employment growth ${ }^{1}$ as a dependent variable was based on the comparison of $R^{2}$ in two regression analysis, which differed only in dependent variable: one using employment growth and the other using employment rate. The regression analysis with employment growth as a dependent variable resulted in higher $R^{2}$, meaning that the proportion of variability explained by the regression line was higher. Other comparable studies on tax wedge-employment relation use as a dependent variable in regression analyses either employment growth or employment rate and other labour market outcomes (for example Võrk et al., 2006) or both (for example Góra et al., 2006). As a macroeconomic control variable we included potential GDP (annual percentage change) and inflation rate. In order to control differences in economic situations among countries and avoid pro-cyclical bias, we took into consideration cyclically adjusted data on GDP based on production function (see European Commission, 2010).

Although the period we analyze is determined by the availability of the data, going further back in the past would not bring clear results in most of the NMS, as their economies were under great influence of the transitional economic and political processes (see Vodopivec et al. (2005) and Võrk et al. (2006)).

The panel data on tax wedge, employment and unemployment rate and potential GDP growth for the EU Member States for 1999-2008 period were obtained from Eurostat (2009), official reports of the European Commission (European Commission 2009a, b and c, 2010) and databases of International Monetary Fund and International Labour Organization.

In order to be comparable among countries, the data on tax wedge are calculated on the basis of OECD methodology for an average worker (single and without children), employed in industry sectors $\mathrm{C}-\mathrm{K}^{2}$ with 67 per cent of average earnings (OECD, 2008). We use the data on average worker with 67 per cent out of two reasons: firstly, availability of the data and secondly, average wages do not present real picture of wage distribution, therefore the median values of income should be considered in the further research. As the data on median of wages are in most countries not available for the period required in our analysis, we believe that indicator of 67 per cent of average earnings is more closely to the actual distribution of wages. ${ }^{3}$

In our analysis we focus on the size of the tax wedge-employment relationship on the labour demand side, while we do not study in detail the effects of factors at the labour supply side and other labour market institutions (for example minimum wage, skills, employment protection legislation, etc.).

1 The variable employment growth refers to the increase in the number of persons employed (fulland part-time) and covers all economic sectors. The Eurostat does not provide data on employment growth for sectors $\mathrm{C}-\mathrm{K}$ for workers with low average wages.

2 According to NACE Rev. 2, sectors C-K were replaced by sectors B-N.

3 In Slovenia, for example, the median of annual gross earnings in 2006 amounted 79.3 per cent of average annual gross earnings (Statistical Office of the Republic of Slovenia, 2009). 


\section{Characteristics of Tax Wedge, Employment and Unemployment Rate in the EU}

There are large differences in the level of tax wedge of the worker with 67 per cent of average earnings among the EU Member States in 2008: at one side, Ireland (16.0 per cent) and Malta (17.9 per cent) stand out with the lowest tax wedge, while on the other hand, Belgium (50.3 per cent), Germany (47.3 per cent) and Hungary (46.7 per cent) exhibit the highest level of tax wedge in the EU-27. The average tax wedge in EU-27 amounts 36.5 per cent, what is 3 percentage points higher than the average of the OECD countries (see Table 1).

In EU-15 the average tax wedge in 2008 amounts 38.1 per cent, whereas in NMS-12 only 34.4 per cent. The difference in average tax wedge between EU-15 and NMS-12 is not statistically significant $(p=0.297$ ), probably due to high variability $(0.4)$ of tax wedge in NMS-12. However, if we look the distribution of tax wedge in NMS-12, we notice that in eight NMS the tax wedge is higher than is the average of the EU-15 (see Table 1). This implies that such a low average tax wedge in NMS-12 could be reasoned with the level of tax wedge in Cyprus ( 0.0 per cent) and Malta $(17.9$ per cent $) .{ }^{4}$ It also signifies that in further analysis two facts should be taken into consideration. Firstly, a more appropriate measure of comparison between EU-15 and NMS-12 is median tax wedge which in NMS-12 amounts 39.3 per cent (4.9 percentage points above its average), whereas in EU-15 38.9 per cent. And secondly, Cyprus and Malta should be studied separately from other (Central and Eastern) NMS. ${ }^{5}$ This is in line with the studies of Ederveen and Thissen (2004), Võrk et al. (2006) and Behar (2009), who on the basis of Principal Component Analysis suggested that CEE-10 share similar characteristics to each other and should be with regard to their labour market policies and institutions classified separately from the rest of the EU Member States.

A simple descriptive statistical analysis has shown that the average tax wedge of an adult with 67 per cent of average earnings is 1.4 percentage points higher in CEE-10 than in EU-15 (it amounts 39.5 per cent in CEE-10 and 38.1 per cent in EU-15, however the difference is not statistically significant), whereas the median value in CEE-10 is only 1.1 percentage point higher. However, as it could be seen from the Figure 1, the height of the boxes and the distances between minimum and maximum values of the tax wedge indicate higher heterogeneity in tax wedge within EU-15.

4 The low level of tax wedge in Cyprus and Malta might be linked to their historical ties to Britain, as also Ireland and United Kingdom show one of the lowest tax wedge in EU-15 (European Commission, 2009a).

5 In the text we refer to the ten Central and Eastern NMS with abbreviation CEE-10. 
Table 1

Tax Wedge of an Adult (single and without children) with 67 per cent of Average Earnings, Employment and Unemployment Rate in the EU in 2008 (in per cent)

\begin{tabular}{|c|c|c|c|}
\hline Country $^{a}$ & Tax wedge $^{b}$ & Employment rate & Unemployment rate \\
\hline Belgium & 50.3 & 62.4 & 7.0 \\
\hline Germany & 47.3 & 70.7 & 7.3 \\
\hline Hungary & 46.7 & 56.7 & 7.8 \\
\hline France & 45.5 & 64.9 & 7.8 \\
\hline Austria & 44.4 & 72.1 & 3.8 \\
\hline Italy & 43.0 & 58.7 & 6.8 \\
\hline Sweden & 42.5 & 74.3 & 6.2 \\
\hline Netherlands & 41.7 & 77.2 & 2.8 \\
\hline Lithuania & 40.3 & 64.3 & 5.8 \\
\hline Slovenia & 40.3 & 68.6 & 4.4 \\
\hline Romania & 40.1 & 59.0 & 5.8 \\
\hline Czech Republic & 40.0 & 66.6 & 4.4 \\
\hline Latvia & 39.9 & 68.6 & 7.5 \\
\hline Denmark & 38.9 & 78.1 & 3.3 \\
\hline Poland & 38.7 & 59.2 & 7.1 \\
\hline Finland & 38.3 & 71.1 & 6.4 \\
\hline Estonia & 38.2 & 69.8 & 5.5 \\
\hline Greece & 37.2 & 61.9 & 7.7 \\
\hline Slovak Republic & 36.1 & 62.3 & 9.5 \\
\hline Bulgaria & 35.1 & 64.0 & 5.6 \\
\hline Spain & 33.8 & 64.3 & 11.3 \\
\hline Portugal & 32.9 & 68.2 & 7.7 \\
\hline United Kingdom & 29.7 & 71.5 & 5.6 \\
\hline Luxemburg & 29.6 & 63.4 & 4.9 \\
\hline Malta & 17.9 & 55.3 & 5.9 \\
\hline Ireland & 16.0 & 67.6 & 6.0 \\
\hline Cyprus & 0.0 & 70.9 & 3.6 \\
\hline Average EU-27 & 36.5 & 66.4 & 6.2 \\
\hline Median & 38.9 & 66.6 & 6.0 \\
\hline Standard deviation & 10.7 & 6.0 & 1.9 \\
\hline Coefficient of variation & 0.3 & 0.1 & 0.3 \\
\hline Average EU-15 & 38.1 & 68.4 & 6.3 \\
\hline Median & 38.9 & 68.2 & 6.4 \\
\hline Standard deviation & 8.7 & 5.8 & 2.1 \\
\hline Coefficient of variation & 0.2 & 0.1 & 0.3 \\
\hline Average NMS-12 & 34.4 & 63.8 & 6.1 \\
\hline Median & 39.3 & 64.2 & 5.8 \\
\hline Standard deviation & 12.8 & 5.3 & 1.7 \\
\hline Coefficient of variation & 0.4 & 0.1 & 0.3 \\
\hline
\end{tabular}

Notes:

a EU Member States are sorted in descending order according to tax wedge.

b Tax wedge on labour is the coefficient between all taxes on labour and social security contribution payments, paid by employer and employee, and total cost of an employee for employer.

Sources: Eurostat, 2009; own calculations. 
Figure 1

Comparison of Tax Wedge on an Adult with 67 per cent of Average Earnings in EU-15 and CEE-10, 2008 (in per cent)
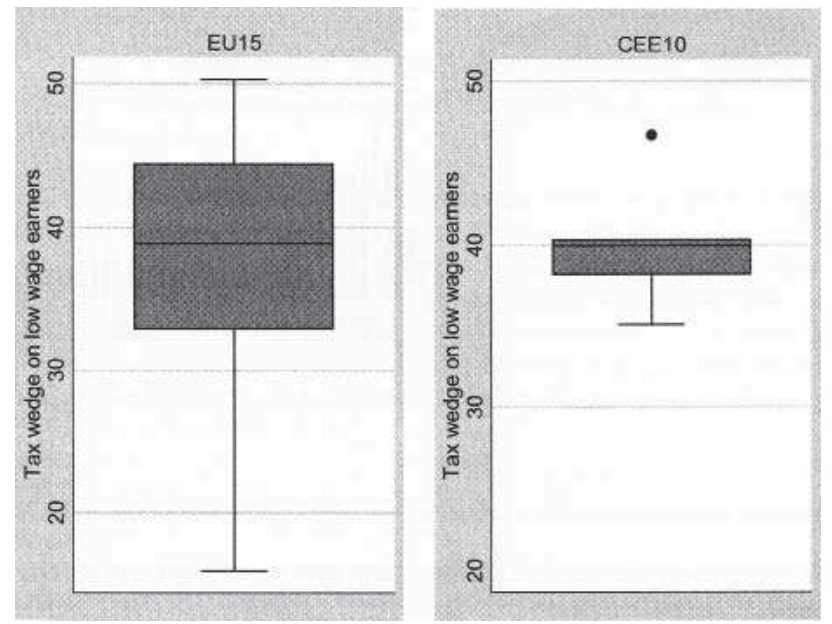

Note:

The horizontal line inside the shaded box is the median value of the group. The bottom edge of the shaded box presents 25th percentile and the upper edge 75th percentile. The horizontal lines outside the box indicate the largest and the smallest value in the sample. The dot in boxplot of CEE-10 indicates the largest value in the sample of CEE-10 (46.7 per cent). Similar analysis on tax wedge for year 2005 was performed by Behar (2009).

Sources: Table 1; own calculations.

Regarding the average employment rate, there is statistically significant difference between EU-15 and NMS-12 (at $p=0.041$ ): the average employment rate in EU-15 is 68.4 per cent, whereas in NMS-12 is 63.8 per cent. The average employment rate in CEE-10 is 63.9 per cent. Although we witness a trend of gradual increase in average employment rate in EU-27 between 1999 and 2008, only eight EU Member States reached a Lisbon target employment rate of 70 per cent in 2008, among NMS-12 only Cyprus. On the other hand, the difference in unemployment rate between EU-15 and NMS-12 is not statistically significant: the average unemployment rate in EU-15 amounts 6.3, while in NMS-12 6.1 (see Table 1).

Descriptive statistics indicate that the EU Member States differ according to tax wedge and employment and unemployment rate; however we cannot offer a uniform conclusion regarding the relationship between tax wedge and employment. Therefore, a hierarchical cluster analysis ${ }^{6}$ has been applied to identify the groups of EU Member States that are similar to each other according to unemployment and employment rate. The cluster analysis divided EU countries into two groups. ${ }^{7}$ The first group is characterized with higher unemployment and lower employment rate

6 The variables used are standardized in order to avoid the influence of different averages on the relative importance of the variable.

7 First group is composed of the following countries: Belgium, Bulgaria, France, Greece, Hungary, Italy, Lithuania, Luxemburg, Malta, Poland, Romania, the Slovak Republic and Spain. Second group includes Austria, Cyprus, the Czech Republic, Denmark, Estonia, Finland, Germany, Ireland, Latvia, the Netherlands, Portugal, Slovenia, Sweden and the United Kingdom. 
and therefore higher tax wedge, whereas the second group has lower unemployment, higher employment rate and lower tax wedge. The differences in unemployment and employment rates between two groups of EU countries are significant, however, the differences in tax wedge are not significant, probably due to high variance in both groups (see Table 2).

Table 2

Characteristics of Two Groups of EU Member States Clustered with Respect to Unemployment and Employment rates, 2008 (in per cent)

\begin{tabular}{|c|c|c|c|c|}
\hline Group & & Tax wedge $^{a}$ & Unemployment rate & Employment rate \\
\hline 1 & $(n=13)$ & $38.0 \pm 8.3$ & $7.2 \pm 1.8$ & $61.3 \pm 3.2$ \\
\hline 2 & $(n=14)$ & $35.0 \pm 12.6$ & $5.3 \pm 1.6$ & $71.1 \pm 3.4$ \\
\hline Total & $(n=27)$ & $36.5 \pm 10.7$ & $6.2 \pm 1.9$ & $66.4 \pm 6.0$ \\
\hline $\begin{array}{l}\text { t-test } \\
\text { (p) }\end{array}$ & & $\begin{array}{l}0.728 \\
(0.474)\end{array}$ & $\begin{array}{c}-7.742 \\
(0.000)\end{array}$ & $\begin{array}{l}2.824 \\
(0.009)\end{array}$ \\
\hline
\end{tabular}

Note:

${ }^{a}$ Data for an adult (single and without children) with 67 per cent of average earnings.

Sources: Eurostat, 2009; own calculations.

The tax wedge decreased in 20 EU Member States in 2008 compared to 1999, by which reductions appear to be particularly large in Cyprus, Romania, the Slovak Republic, Sweden, Ireland and Finland (all above 4 percentage points). Among the countries that have increased the tax wedge in this period, Malta and France show the highest increase with 5.4 and 5.2 percentage points, respectively (Eurostat, 2009; own calculations). To a large extent, the reduction in tax wedge is almost entirely driven by the reduction in personal income taxation and in social security contributions of employers (European Commission, 2009a).

As it can be seen from the Figure 2, the average tax wedge in EU-27 was slowly declining after year 2000 , reaching 37.9 per cent in 2003. It continued to decrease after 2004. On average, the tax wedge in the EU-27 decreased by 1.4 percentage points between 1999 and 2008, however the CEE-10 together with three Nordic countries show a much stronger decline (on average 3.2 percentage points or 0.36 percentage points/year.). The median values for EU-27 during the period 1999-2008 lie above the average of the EU-27, indicating that the tax wedge in majority of the Member States is above the average of the EU-27. What is more, in contrast to a gradual decline in average tax wedge between 2000 and 2008, the median values show a different picture: after decline between 2000 and 2004 (40.8 per cent), the median value of tax wedge increased twice: in 2005 (41.4 per cent) and 2007 (40.6 per cent), following a decline in a year after (see Figure 2). Such a strong decline in 2008 can be explained by a decrease in tax wedge across most of the Member States (15, in some states rather strong) and rather a small increase in other Member States.

The high tax wedge group shows a gradual slow decrease in average tax wedge between 2000 and 2005, when it reached rather stable average tax wedge around 38 per cent. On the other hand, the trend in average tax wedge in the low tax wedge group 
is more dynamic (see Figure 2). On average, the tax wedge between 1999 and 2008 in high tax wedge group decreased by 0.7 percentage points and by 2.1 percentage points in low tax wedge group. The annual rate of decline in average tax wedge is $0.08 \mathrm{in} \mathrm{high}$ tax wedge group and 0.23 in low tax wedge group.

Figure 2

Tax Wedge on Labour, 1999-2008 (in per cent)

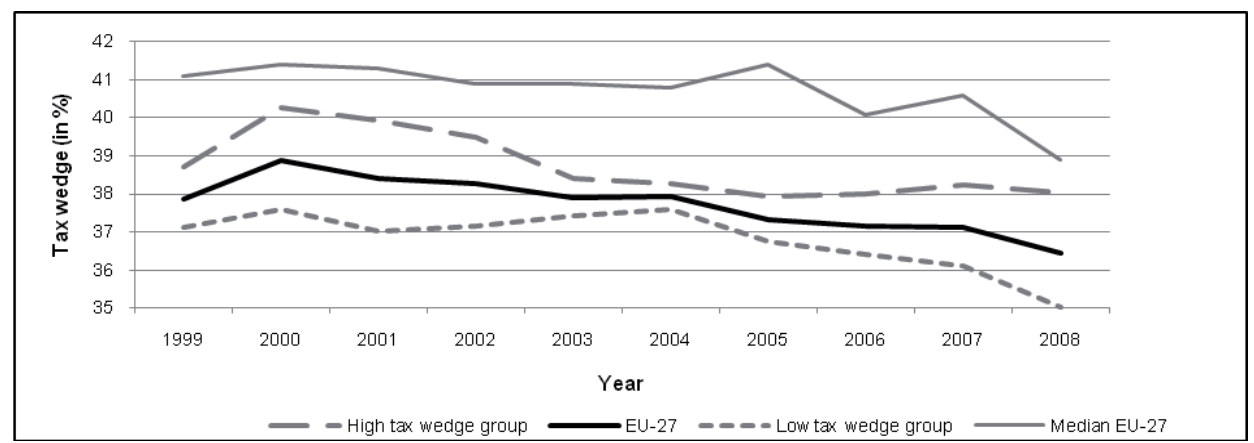

Sources: Eurostat, 2009; own calculations.

\section{Effect of Tax Wedge on Employment Growth}

In order to analyze the relationship between tax wedge and employment growth, we first use simple two-variable cross-country scatter diagrams to plot employment growth and tax wedge. The results showed that there is a weak negative correlation between tax wedge and employment growth among the EU Member States in 2008: there is almost no relationship between employment growth and tax wedge within the EU-15, but there is a negative correlation between tax wedge and employment growth within NMS. The negative correlation between tax wedge and employment growth is even stronger in CEE-10. ${ }^{8}$ The same analysis was repeated with the groups obtained in cluster analysis. The high tax wedge group of EU countries showed a strong negative correlation between tax wedge and employment growth in 2008, however we could not see any relation in low tax wedge group (see Figures 3 and 4). ${ }^{9}$

8 Coefficient of correlation between tax wedge and employment growth in CEE-10 countries equals -0.663 and is statistically significant $(p=0.037)$. Across NMS- 12 the coefficient of correlation is lower and equals -0.383 , however, is not statistically significant $(p=0.220)$.

9 Coefficient of correlation between tax wedge and employment growth within high tax wedge group equals $-0.451(p=0.120)$. There is rather no correlation in low tax wedge group $(-0.016)$. Nevertheless, the correlations are not statistically significant. 
Figure 3

Tax Wedge and Employment Growth in High Tax Wedge EU Countries in 2008 (first group in cluster analysis)

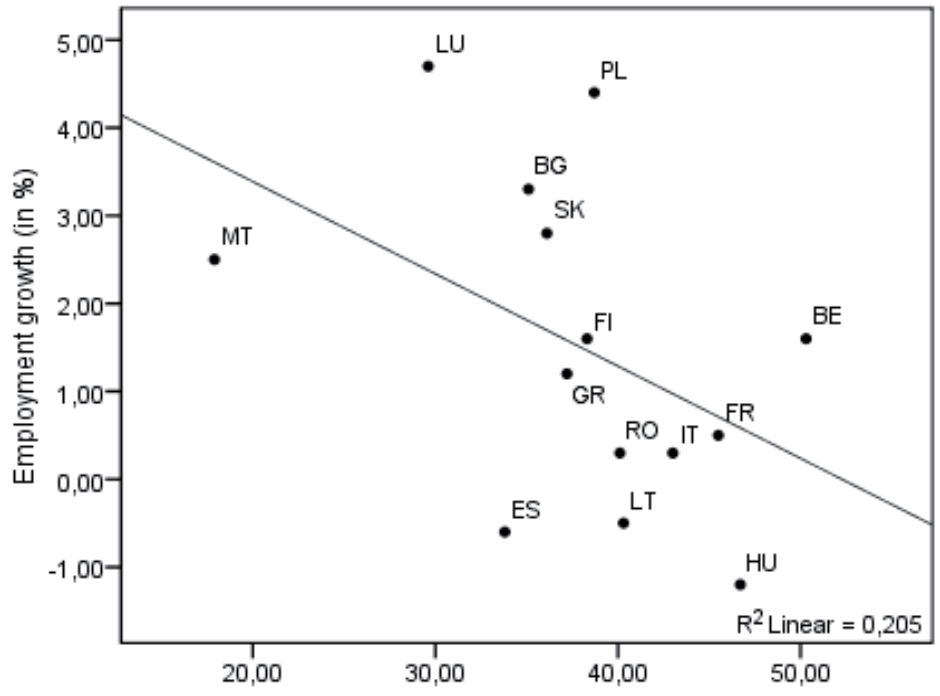

Tax wedge (an adult with $67 \%$ of average earnings, in \%)

Sources: Table 1; Eurostat, 2009; own calculations.

Figure 4

Tax Wedge and Employment Growth in Low Tax Wedge EU Countries in 2008 (second group in cluster analysis)

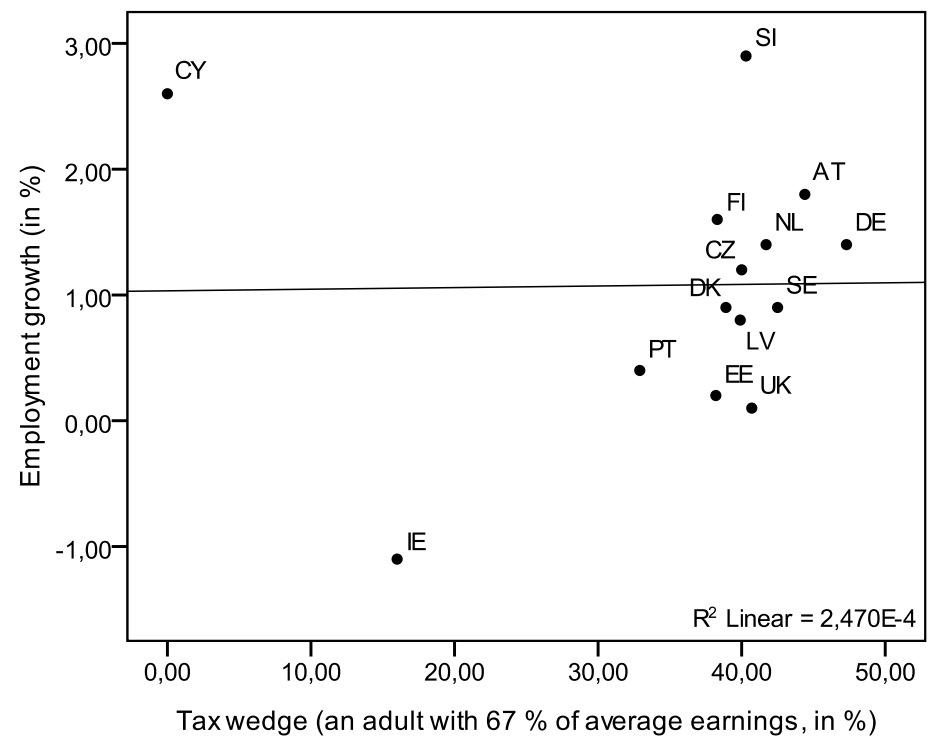

Sources: Table 1; Eurostat, 2009; own calculations. 
In order to check the tax wedge-employment growth relation in more detail also on our sample of countries during the 1999-2008 period, we conducted panel data regression analysis. The estimates of the panel regression (see Table 3) showed that, at a given potential GDP growth, an increase in tax wedge results in the decrease of the employment growth in all three studied groups. Namely, in EU-27 an increase in tax wedge for one percentage point results in a decrease in employment growth by around 0.04 percentage points, at a given potential GDP growth (the coefficient is statistically significant)..$^{10}$ The negative relationship between tax wedge and employment growth is stronger in low tax wedge EU group, as an increase in tax wedge for one percentage point is associated with a decrease in employment growth by around 0.05 percentage points (the coefficient is statistically significant). The latter was confirmed also in panel regression analysis using dummy variables. As the estimations of tax wedge are significant in all three studied groups, they not only show the direction of relation between tax wedge and employment in the EU, but they again confirm the negative effect of tax wedge on employment growth.

Table 3

Estimation Results of the Linear Regression with Panel-Corrected Standard Errors

\begin{tabular}{|l|l|r|r|r|r|}
\hline $\begin{array}{l}\text { Studied group of } \\
\text { countries }\end{array}$ & Employment growth & Coefficient & S. E. & Z & $p>|z|$ \\
\hline \multirow{4}{*}{ EU-27 } & Tax wedge & -0.043 & 0.009 & -4.75 & 0.000 \\
\cline { 2 - 6 } & Potential GDP growth & 0.354 & 0.124 & 2.85 & 0.004 \\
\cline { 2 - 6 } & Inflation rate & -0.099 & 0.041 & -2.41 & 0.016 \\
\cline { 2 - 6 } & Constant & 2.047 & 0.545 & 3.76 & 0.000 \\
\cline { 2 - 6 } & R-squared & 0.199 & \multicolumn{4}{|c|}{} \\
\hline \multirow{4}{*}{$\begin{array}{l}\text { high tax wedge EU } \\
\text { countries }\end{array}$} & Tax wedge & -0.036 & 0.012 & -2.90 & 0.004 \\
\cline { 2 - 6 } & Potential GDP growth & 0.449 & 0.187 & 2.40 & 0.016 \\
\cline { 2 - 6 } & Inflation rate & -0.114 & 0.044 & -2.58 & 0.010 \\
\cline { 2 - 6 } & Constant & 1.627 & 0.856 & 1.90 & 0.057 \\
\cline { 2 - 6 } & R-squared & 0.211 & \multicolumn{4}{|c}{} \\
\hline \multirow{4}{*}{$\begin{array}{l}\text { low tax wedge EU } \\
\text { countries }\end{array}$} & Tax wedge & -0.049 & 0.015 & -3.26 & 0.001 \\
\cline { 2 - 6 } & Potential GDP growth & 0.242 & 0.123 & 1.97 & 0.049 \\
\cline { 2 - 6 } & Inflation rate & 0.023 & 0.106 & 0.22 & 0.827 \\
\cline { 2 - 6 } & Constant & 2.196 & 0.752 & 2.92 & 0.004 \\
\cline { 2 - 6 } & R-squared & 0.219 & & \\
\hline
\end{tabular}

Sources: Eurostat, 2009; own calculations.

The findings are, in general, in line with various empirical studies on the sample of OECD countries and EU Member States that found a negative relation between

10 The panel data analysis also shows that there is strong negative relationship between tax wedge and employment growth in NMS-12 (an increase in one percentage point in the tax wedge is, at given GDP rate, associated with a decrease in employment growth by -0.08 percentage points, the coefficient is statistically significant). In EU-15 the relation is not significant. 
tax wedge and employment. For example, Ederveen and Thissen (2004) found a statistically significant positive relationship between unemployment rate and tax wedge on the sample of four CEE countries. Also Góra et al. (2006) showed a strong and significant negative relationship between employment growth and tax wedge in $\mathrm{CEE}$ and a strong impact of tax wedge employment rates of low-skilled workers. Behar (2009) as well concluded that high tax wedge and inappropriate benefit system are associated with poor labour market outcomes, but the evidence was weak.

\section{Concluding Remarks and Policy Recommendations}

In this paper we assessed the characteristics of tax wedge, employment and unemployment rate in the EU Member States in 2008 and by using linear regression with panel-corrected standard errors analyzed whether the tax wedge affected the employment growth in the EU Member States between 1999 and 2008.

The findings of the paper imply that a reduction in taxes on labour could increase demand on labour and employment as it would motivate the employers to create jobs, especially for low-wage workers, and increase people's willingness to work (OECD 2009a, b). The establishment of the employment-friendly wage is also crucial for increasing productivity and improving general economic framework in the EU (European Commission, 2005). Several Member States have already taken measures to reduce tax wedge such as reducing social security contributions for disadvantages groups, lowering tax threshold for personal income tax, tightening the provision of contributions for self-employment, changing the legislation in the field of minimum wages and social security contributions, increase in nominal wages, etc. (more information on measures across the EU Member States are available in quarterly reports of the European Employment Observatory (2009) and in Carone et al. (2009)).

Policy recommendation following from our empirical analysis is clear: the EU should continue with the trend of reducing tax wedge, as this would increase employment, decrease unemployment and consequently lead to higher productivity and improve competitiveness. The average employment rate in EU-27 in 2008 equals 66.4 per cent, meaning that in order to reach a Lisbon target the EU-27 should increase its average employment rate by 3.6 percentage points. To achieve this, the EU-27 should, according to our regression analysis, decrease the tax wedge by approximately 5 percentage points, ceteris paribus. In high tax wedge group, the reduction in tax wedge should be even higher, as the average employment rate is 61.3 per cent. The low tax wedge group has, on average already reached the Lisbon target. However, the reduction in tax wedge is not sufficient measure to increase employment, as the high unemployment rate in many EU Member States is also the consequence of high unemployment benefits, wage bargaining system and powerful labour unions, employment protection legislation, differences in distribution of wages within EU, etc.

To conclude, the findings of this paper are, in general, in line with previous empirical research, as the empirical estimates confirm the detrimental effect of tax wedge on employment growth. However, one has to remember also the limitations of these findings deriving from the availability of good time series information on tax wedge, its composition, and other labour market outcomes; small number of variables used and therefore possible formation of omitted variables problem; and insufficient 
sources of variation and low value of R-squared. The analysis also does not take into the account the effect of global economic and financial crisis, as its impact on real economy were not evident in year 2008. Therefore, a further analysis on a country by country basis and analysis considering the effects of economic and financial crisis are needed.

\section{References}

Alesina, A., Perotti, R. (1997), "The Welfare State and Competitiveness." American Economic Review, 87 (5), pp. 921-39.

Alphametrics (2009), Flexicurity: Indicators on the Coverage of Certain Social Protection Benefits for Persons in Flexible Employment in the European Union. Final report. Royston: Alphametrics.

Bassanini, A., Duval, R. (2006), "Employment Patterns in OECD Countries: Reassessing the Role of Policies and Institutions." OECD Economics Department Working Paper No. 486.

Beck, N., Katz J. R. (1995), "What to Do (and Not to Do) with Time-Series Cross-Section Data." American Political Science Review, 89, pp. 634-647.

Behar, A. (2009), "Tax Wedges, Unemployment Benefits and Labour Market Outcomes in the New EU Members." AUCO Czech Economic Review, 3, pp. 71-94.

Belot, M., van Ours, J. C. (2004), "Does the Recent Success of Some OECD Countries in Lowering their Unemployment Rates Lie in the Clever Design of their Labour Market Reforms?" Oxford Economic Papers, 56 (4), pp. 621-42.

Carone, G., Stovicek, K., Pierini, F., Sail, E. (2009), "Recent Reforms of the Tax and Benefit Systems in the Framework of Flexicurity." European Commission - Directorate General for Economic and Financial Affairs Occasional Paper No. 43.

Daveri, F., Tabellini, G. (2000), "Unemployment, Growth and Taxation in Industrial Countries." Economic Policy, 15 (30), pp. 47-104.

Ederveen, S., Thissen, L. (2004), "Can Labor Market Institutions Explain Unemployment Rates in New EU Member States?" European Network of Economic Policy Research Institute Working Paper No. 27.

Elmeskov, J., Martin, J., Scarpetta, S. (1998), "Key Lessons for Labour Market Reforms: Evidence from OECD Countries' Experiences." Swedish Economic Policy Review, 5 (2), pp. 205-52.

European Commission (2005), Integrated Guidelines for Growth and Jobs (2005-2008) including a Commission Recommendation on the Broad Guidelines for the Economic Policies of the Member States and the Community (under Article 99 of the EC Treaty) and a Proposal for a Council Decision on Guidelines for the Employment Policies of the Member States (under Article 128 of the EC Treaty). COM(2005) 141 final. Brussels: European Commission.

European Commission (2009a), Taxation Trends in the European Union - Data for the EU Member States and Norway. Luxembourg: Office for Official Publications of the European Communities.

European Commission (2009b), Employment in Europe 2009. Luxembourg: Office for Official Publications of the European Communities.

European Commission (2009c), Europe in Figures - Eurostat Yearbook 2009. Luxembourg: Office for Official Publications of the European Communities.

European Commission (2010), Cyclical Adjustment of Budget Balances. Luxembourg: Office for Official Publications of the European Communities.

European Employment Observatory (2009), "Quarterly Reports.“ Birmingham: European Employment Observatory.

Eurostat (2009), "Labour Market." Eurostat, Statistical Database.

Flaig, G., Rottmann, H. (2007), "Labour Market Institutions and the Employment Intensity of Output Growth. An International Comparison." CESifo Working Paper No. 217. 
García, J. R., Sala, H. (2006), "The Tax System Incidence on Unemployment: A Country-Specific Analysis for the OECD Economies." The Institute for the Study of Labor Discussion Paper No. 226.

Goerke, L. (1999), "The Wedge." The Institute for the Study of Labor Discussion Paper No. 71.

Góra, M., Radziwiłł, A., Sowa, A., Walewski, M. (2006), Tax Wedge and Skills: Case of Poland in International Perspective. Report No. 64/2006. Warsaw: Center for Social and Economic Research.

Gruber, J. (1997), "The Incidence of Payroll Taxation: Evidence from Chile.“ Journal of Labor Economics, 15 (3), pp. S72-101.

de Haan, J., Sturm, J. E., Volkerink, B. (2003), "How to Measure the Tax Burden on Labour at the Macro-Level." CESifo Working Paper No. 963.

Koskela, E. (2001), "Labour Taxation and Employment in Trade Union Models: a Partial Survey." Bank of Finland Discussion Papers No. 19/2001.

Koskela, E., Schöb, R. (2007), "How Tax Progression Affect Effort and Employment." The Institute for the Study of Labor Discussion Paper No. 2861.

Kugler, A., Kugler, M. (2003), "The Labor Market Effects of Payroll Taxes in a Middle-Income Country: Evidence from Colombia." The Institute for the Study of Labor Discussion Paper No. 852/2003.

Muysken, I., Van Veen, T., de Regt, E. (1999), "Does a Shift in the Tax Burden Create Employment?.“ Applied Economics 31, pp. 1195-1205.

Nickell, S., Layard, R. (1999), "Labour Market Institutions and Economic Performance," in Ashenfelter, O., Card, D., ed., Handbook of Labor Economics. Amsterdam: North Holland, pp. 3029-3084.

Nickell, S. (2003), "Employment and Taxes." CESifo Working Paper No. 1109.

OECD (2003), Employment Outlook 2003. Paris: Organization for Economic Cooperation and Development.

OECD (2004), Employment Outlook 2004. Paris: Organization for Economic Cooperation and Development.

OECD (2006), OECD Employment Outlook: Boosting Jobs and Incomes. Paris: Organization for Economic Cooperation and Development.

OECD (2007), Employment Outlook 2007. Paris: Organization for Economic Cooperation and Development.

OECD (2008), Taxing Wages 2007-2008. Paris: Organization for Economic Cooperation and Development.

OECD (2009a), OECD Employment Outlook: Tackling the Job Crisis. Paris: Organization for Economic Cooperation and Development.

OECD (2009b), OECD Reviews of Labour Market and Social Policies: Slovenia. Paris: Organization for Economic Cooperation and Development.

Statistical Office of the Republic of Slovenia (2009), "Rapid Report: Labor Market, No. 9“. Ljubljana: Statistical Office of the Republic of Slovenia.

Vodopivec, M. (2005), Income Support for the Unemployed. Issues and Options. Washington, DC: World Bank.

Vodopivec, M. (2006), "Choosing a System of Unemployment Income Support: Guidelines for Developing and Transition Countries." World Bank Research Observer, 21 (1), pp. 49-89.

Vodopivec, M., Wörgötter, A., Dhushyanth, R. (2005), "Unemployment Benefit Systems in Central and Eastern Europe: A Review of the 1990s." Comparative Economic Studies, 47 (4), pp. 615-51.

Võrk, A., Leetmaa, R., Paulus, A., Anspal, S. (2006), "Tax-Benefit System in the New Member States and their Impact on Labour Supply and Employment." PRAXIS Center for Policy Studies Working Paper 29/2006.

World Bank (2005), "Special Topic: Labor Taxes and Employment in the EU-8." World Bank Quaterly Report, April 2005, Part II. 